\title{
Barcode DNA berdasarkan Gen rbcL dan matK Anggrek Payus Limondok (Phaius tancarvilleae) (DNA Barcode of Payus Limondok Orchid (Phaius tancarvilleae) Based on the $r b c L$ and matK genes)
}

\author{
Beivy J. Kolondam 1) *, Edy Lengkong ${ }^{2)}$, J. Polii-Mandang ${ }^{2)}$, \\ Arthur Pinaria ${ }^{2)}$, Semuel Runtunuw ${ }^{2)}$ \\ 1) Jurusan Biologi Fakultas MIPA Universitas Sam Ratulangi Manado \\ 2) Jurusan Agroekoteknologi Fakultas Pertanian dan Program Studi Agronomi Program \\ Pascasarjana Universitas Sam Ratulangi Manado \\ ${ }^{\star}$ Email korespondensi: beivy_jk@yahoo.com
}

Diterima 1 Agustus 2012, diterima untuk dipublikasikan 25 Agustus 2012

\begin{abstract}
Abstrak
Metode identifikasi spesies telah disepakati menggunakan barcode DNA standar yaitu gen rbcL dan gen matK. Tujuan penelitian ini untuk menentukan tingkat kemiripan sekuens barcode DNA tanaman Anggrek Payus Limondok (Phaius tancarvilleae) dengan spesies kerabatnya yang sudah terdata dalam BOLD Systems, merekomendasi penggunaan barcode untuk mengidentifikasi atau mengkonfirmasi spesies ini, dan mengamati variasi intraspesifik. Teknik Polymerase Chain Reaction (PCR) digunakan untuk mengamplifikasi sekuens gen rbcL dan matK melalui primer universal. Barcode rbcL menunjukkan kemiripan 100\% (identik) dengan dua spesies berbeda dalam famili yang sama (Orchidaceae), sehingga tidak bisa diandalkan untuk identifikasi spesies $P$. tancarvilleae secara akurat. Sekuens matK sampel menghasilkan kemiripan $100 \%$ dengan spesies sama yang sebelumnya telah terdata dalam BOLD Systems. Kemiripan ini mengindikasikan rendahnya variasi genetik intraspesies tetapi sekuens matK dapat diandalkan untuk identifikasi atau konfirmasi spesies anggrek $P$. tancarvilleae.

Kata Kunci: barcode, rbcL, matK, Phaius tancarvilleae
\end{abstract}

\begin{abstract}
Species identification methods convention have been recommended to use standard DNA barcode for plants; the rbcL and matK genes. The aims of this research were to determine similarities in barcode DNA sequences of Payus Limondok Orchid (Phaius tancarvilleae) with its close relatives that listed in BOLD Systems, to recommend the use of DNA barcodes for identification or confirmation of this species, and to observe intraspecific variations. Polymerase Chain Reaction technique was employed to amplify rbcL and matK genes using universal primers. The rbcL barcode of Payus Limondok resulted identical hit with other two different species in the same family (Orchidaceae), therefore, unreliable for accurate $P$. tancarvilleae species identification. The matK sequence of this plant was $100 \%$ similar with the same plant species listed in BOLD Systems. This similarity indicated low genetic variation within the species, but the matK sequence was found to be reliable for $P$. tancarvilleae orchid species identification or confirmation.

Keywords: barcode, rbcL, matK, Phaius tancarvilleae
\end{abstract}




\section{PENDAHULUAN}

Metode identifikasi spesies makhluk hidup telah berkembang dari identifikasi morfologi sampai pada identifikasi molekuler berdasarkan potongan DNA pendek yang disebut "barcode DNA" (Hebert et al. 2003). Barcode DNA memiliki fungsi-fungsi aplikatif misalnya untuk survei ekologi (Dick dan Kress 2009), identifikasi takson-takson kriptik (Lahaye et al. 2008), dan konfirmasi sampel-sampel tanaman obat (Xue dan Li 2011). The Consortium for the Barcode of Life (CBOL) merekomendasikan penggunaan dua gen plastida yaitu rbcL dan matK sebagai barcode standar (Hollingsworth et al. 2009). Indonesia sebagai negara megabiodiversitas memiliki berbagai macam sumber daya. Pendataan terhadap keragaman jenis tumbuhan di indonesia harus terus dilakukan untuk memenuhi kebutuhan penelitian dan tujuan praktis di masa depan serta untuk mengimbangi laju hilangnya keragaman. Salah satu tanaman yang populer di Sulawesi Utara yaitu Anggrek Payus Limondok (Phaius tancarvilleae). Tanaman anggrek ini telah dikenal sebagai anggrek khas Sulawesi Utara, tetapi beberapa negara, misalnya Australia dan Thailand, juga terdata memiliki spesies dengan nama yang sama. Untuk itu diperlukan perbandingan secara genetik molekuler dalam membedakan tanaman ini untuk berbagai kepentingan.

Sebagai salah satu instrumen penting dalam penelitian-penelitian yang multidisiplin, barcode DNA perlu disokong oleh ketersediaan database untuk identifikasi. Berdasarkan penelusuran singkat dalam BOLD (Barcode of Life Database) Systems yang terhubung dengan database sekuens dari beberapa negara, data sekuens DNA barcode standar (rbcl dan matK) banyak spesies belum tersedia atau belum lengkap untuk kedua gen barcode. Penelitian ini bertujuan untuk menentukan tingkat kemiripan sekuens DNA barcode tanaman anggrek Payus Limondok dengan spesies kerabatnya yang sudah terdata dalam BOLD Systems, merekomendasi penggunaan barcode DNA untuk identifikasi atau mengkonfirmasi spesies ini, dan mengamati variasi intraspesifik.

\section{METODE}

\section{Ekstraksi DNA Total Tanaman}

DNA diekstrak dari potongan kecil lembaran daun satu tanaman $P$. tancarvilleae menggunakan Multisource Genomic DNA Miniprep Kit (Axygen) sesuai petunjuk manual. Kit ini memanfaatkan teknik purifikasi kolom yang mampu mengektraksi DNA total sel (DNA inti, kloroplas, dan mitokondria). Sel mengalami lisis oleh penggerusan dalam buffer lisis dan Proteinase K. Protein dipresipitasi dan hancuranhancuran sel dipisahkan melalui sentrifugasi pada $14.000 \mathrm{rpm}$ selama tiga menit. Supernatan dilewatkan melalui kolom bermembran silika. DNA total dicuci dari sisa-sisa protein dan garam kemudian dielusikan dalam tabung mikro $1,5 \mathrm{ml}$ dan disimpan dalam suhu $-20^{\circ} \mathrm{C}$.

\section{Polymerase Chain Reaction}

Kit untuk PCR menggunakan 5X Ready-to-Load Master Mix (Solis Biodyne). Kondisi akhir tiap reaksi $50 \mu \mathrm{L}$ yaitu 1.25 Unit Taq DNA polimerase, 0,2 $\mathrm{mM}$ masing-masing dNTPs, $\quad 1,5 \quad \mathrm{mM} \mathrm{MgCl}_{2}, 0,2 \mathrm{mM}$ masing-masing primer dan kira-kira 0,6 $\mu \mathrm{g}$ DNA total sampel. Untuk primer digunakan primer universal yaitu rbcLaF (5'-ATG TCA CCA CAA ACA GAG ACT AAA GC-3') dan rbcLaR (5'-GTA AAA TCA AGT CCA CCR CG-3') untuk amplifikasi gen rbcL (Kress dan Erickson 2007) 
serta untuk gen matK digunakan matK-3F (5'-CGT ACA GTA CTT TTG TGT TTA CGA G-3') dan matK1R (5'-ACC CAG TCC ATC TGG AAA TCT TGG TTC-3').

Pengaturan suhu thermocycler dimulai dengan denaturasi awal pada $95^{\circ} \mathrm{C}$ selama 2 menit kemudian dilanjutkan 35 siklus [95ㅇ 30 detik, $X^{\circ} \mathrm{C} 30$ detik, dan $72^{\circ} \mathrm{C} 1$ menit]. Suhu $X$ untuk perlekatan primer (annealing) yang disarankan

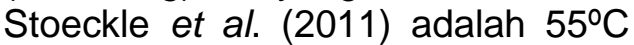
untuk rbcL dan $52^{\circ} \mathrm{C}$ untuk matK. Pita DNA hasil PCR divisualisasi menggunakan elektroforesis gel agarosa $1 \%$ dan dikirim untuk sekuensing ke penyedia jasa sekuensing menggunakan primer yang sama. Sekuensing dilakukan dua kali dengan arah yang berbeda (forward dan reverse).

\section{Analisis Data}

Kromatogram DNA hasil sekuensing disunting menggunakan software Geneious v5.6 (Drummond et al. 2012). Bagian awal DNA dihapus kira-kira 30 bp dan pembacaan nukleotida yang keliru diperbaiki berdasarkan tingkat keakuratan terbaca. Hasil sekuensing yang menggunakan primer reverse dilakukan proses reverse and complement kemudian dipadukan dengan hasil sekuensing primer forward menggunakan MUSCLE (Multiple Sequence Comparison by Log-Expectation) oleh Edgar (2004).

Keakuratan amplifikasi gen target diuji dengan memprediksi urutan asam amino berdasarkan masing-masing sekuens $r b c L$ dan matK. Hal ini bertujuan untuk melihat adanya kodon stop (UAA, UAG atau UGA) di tengah sekuens gen-gen aktif tersebut sehingga diketahui pasti bahwa yang teramplifikasi bukan gen semu (pseudogene). Potongan gen rbcL dan matK diidentifikasi lewat BOLD (Barcode of Life Database) Systems (www.boldsystems.org)

(Ratnasingham dan Hebert 2007).

\section{HASIL DAN PEMBAHASAN}

Kromatogram hasil sekuensing menampilkan hasil yang berkualitas tinggi. Nilai $\mathrm{HQ \%}$ kromotogram yang terbaca dalam Geneious v5.6 menunjukkan nilai $>91.0 \%$ untuk rbcL dan $>97.0 \%$ untuk matK (data tidak ditampilkan). Sampel $P$. tancarvilleae memiliki 599 bp sekuens rbcL dan 889 bp sekuens matK. Pengujian terhadap asam amino yang dikode dari sekuens DNA kloroplas ini menunjukkan tidak adanya kodon stop di tengah-tengah sekuens (Gambar 1 dan Gambar 2). Hal ini berarti bahwa hasil amplifikasi DNA yang dilakukan bersifat valid mengingat kedua gen tersebut adalah fragmen yang termasuk dalam bingkai bacaan terbuka (open reading frame) enzimenzim fotosintesis. Gen $r b c L$ menggunakan frame 1 (pembacaan dimulai asam dari amino pertama) sedangkan gen matK menggunakan frame 3 (pembacaan dimulai dari asam amino ketiga).

Penelusuran dalam BOLD Systems untuk sekuens $r b c L$ sampel PL (Payus Limondok) menghasilkan tingkat kemiripan 100\% (identik) dengan Coelia macrostachya dan $C$. densiflora (Gambar 3). Konfirmasi jenis anggrek dilakukan dengan mencocokkan tanaman sampel PL dengan gambar kedua tanaman yang mirip dalam Pfahl (2012a dan 2012b) dan ternyata terdapat perbedaan nyata berdasarkan morfologi bunga. Ini berarti gen $r b c L$ ini terkonservasi dan barcode rbcL tidak mampu untuk membedakan beberapa anggota famili Orchidaceae yang berkerabat dekat. Dugaan ini semakin diperkuat dengan adanya 15 spesies lain yang semuanya memiliki tingkat kemiripan 
yang tinggi dan persentase yang sama saat dibandingkan dengan sampel PL yaitu 99,82\%. Pencocokan sekuens matK sampel $\mathrm{PL}$ menghasilkan tingkat kemiripan $100 \%$ (identik) dengan spesies $P$. tancarvilleae yang sudah terdata di dalam BOLD Systems (Gambar 4). Terdapat dua specimen dari spesies ini yang berbeda cakupan panjang (837 bp dan 786 bp) dan keduanya identik dengan sekuens sampel PL. Perbandingan dengan spesies lain dalam database menghasilkan tingkat kemiripan kurang dari $98 \%$. Spesies-spesies yang mirip juga berasal dari genus yang bervariasi tetapi masih termasuk dalam famili Orchidaceae. Ini menandakan bahwa barcode berdasarkan gen matK telah mampu membedakan spesies ini dengan baik dan bisa dimanfaatkan untuk identifikasi, meskipun hanya menggunakan barcode DNA tunggal.

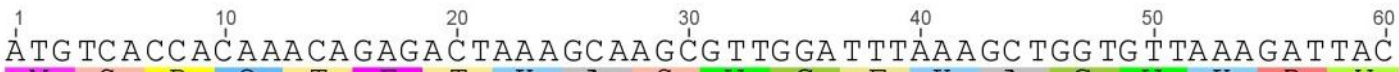

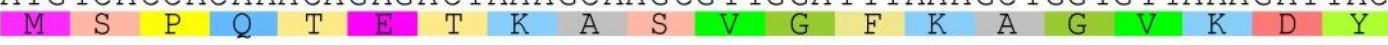
$\begin{array}{lllll}70 & 80 & 90 & 100 & 110\end{array}$

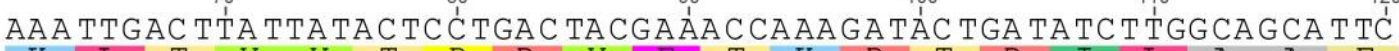

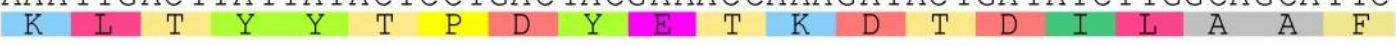
$130 \quad 140 \quad 150 \quad 160 \quad 170 \quad 180$

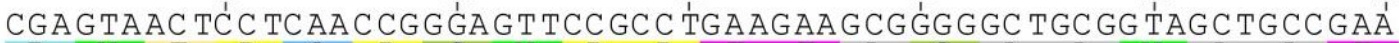
\begin{tabular}{lllllllllllllllllllll}
$R$ & $V$ & $T$ & $P$ & $Q$ & $P$ & $G$ & $V$ & $P$ & $P$ & $E$ & $E$ & $A$ & $G$ & $A$ & $A$ & $V$ & $A$ & $A$ & $E$ \\
\hline
\end{tabular} $190 \quad 200 \quad 210 \quad 220 \quad 230 \quad 240$ TC T TC TAC TGG TACA TGGA CAAC TGTGTG

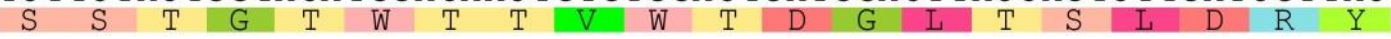
$250 \quad 260 \quad 270 \quad 280 \quad 300$ AAAGGACGATGCTACCACA TCGA G TCG T TG TTG GG GAGGAAAA TCA TA TA TTGCT TA T

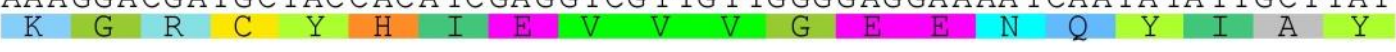

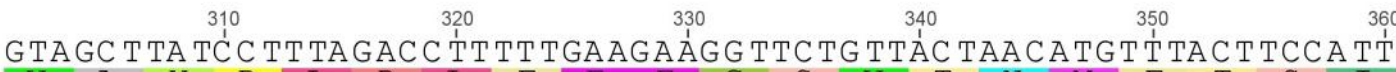

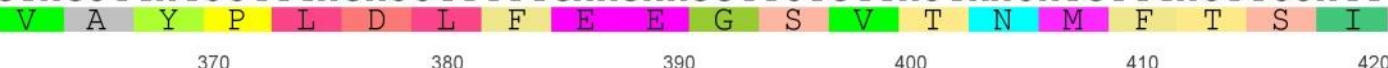

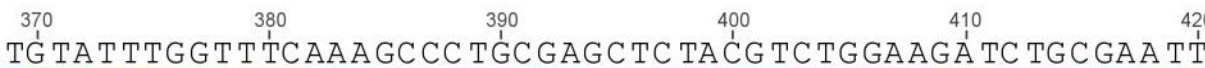

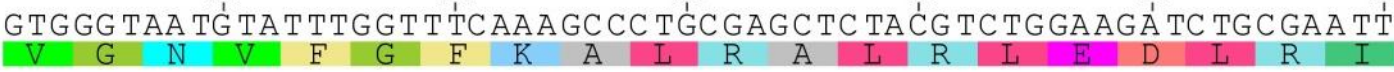

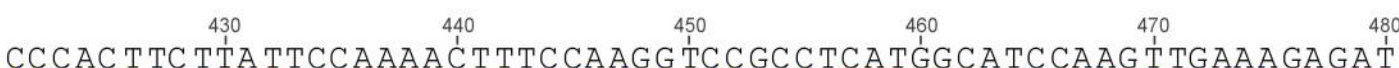
$\mathrm{P} \mathrm{T}_{\mathrm{S}} \mathrm{Y} \mathrm{S}$ K T F Q G P P H G I Q V E R D $490 \quad 500 \quad 510 \quad 520 \quad 530 \quad 54$

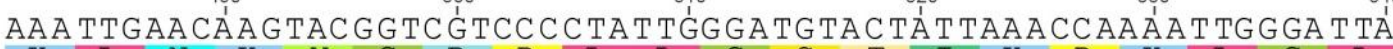

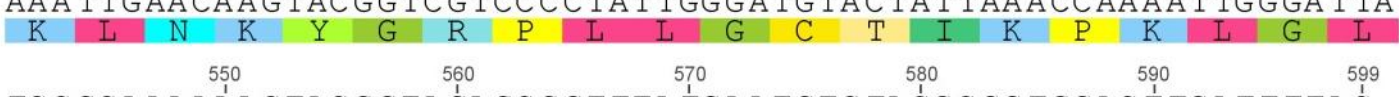

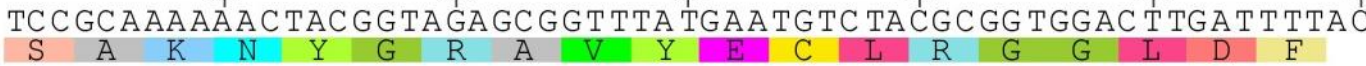

Gambar 1. Sekuens DNA barcode rbcL dan Asam Amino 


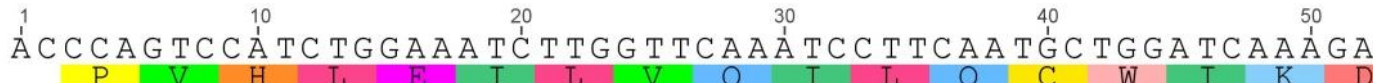

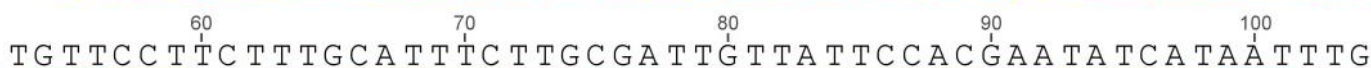

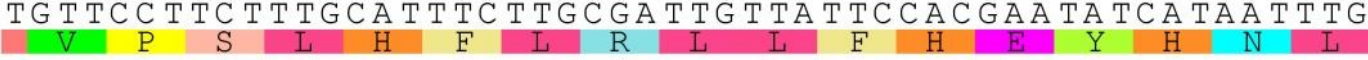
$110 \quad 120 \quad 130 \quad 140 \quad 150$

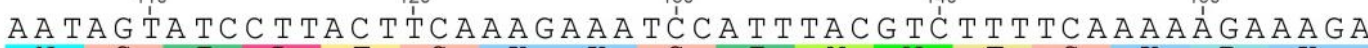
$\mathrm{N} S \mathrm{~S} \mathrm{~L}_{\mathrm{T}} \mathrm{S} \mathrm{K}_{\mathrm{K}} \mathrm{S}_{\mathrm{I}} \mathrm{Y}_{\mathrm{V}} \mathrm{F}_{\mathrm{S}} \mathrm{K}_{\mathrm{K}}$ $160 \quad 170 \quad 180 \quad 190 \quad 200$

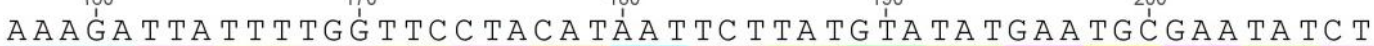

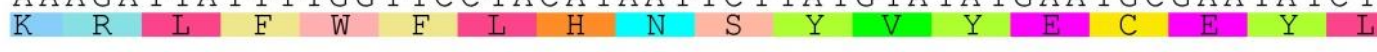

$210 \quad 220 \quad 230 \quad 240 \quad 250 \quad 260$ A T TC T T T TA TTCG TAA A A

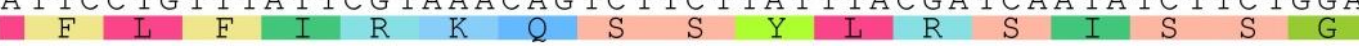
$270 \quad 280 \quad 390 \quad 310$ G TC T T T T T GA GCGAACAC

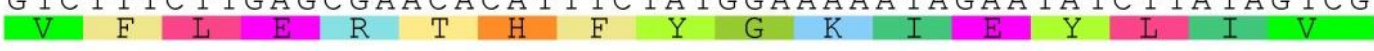
$320 \quad 330 \quad 340 \quad 350 \quad 360$

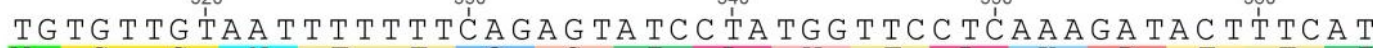

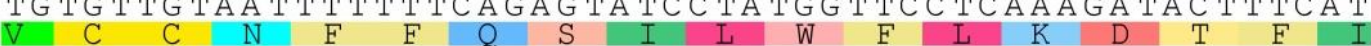
$370 \quad 380 \quad 390 \quad 400 \quad 410$

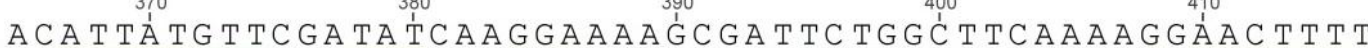

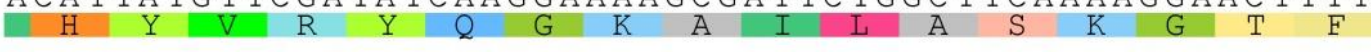

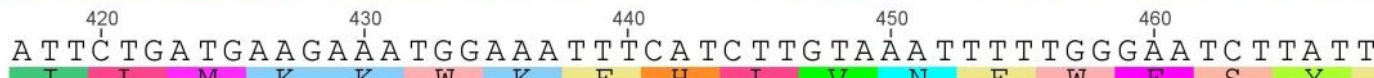
I L M K K W K F H L V N F W E S Y $470 \quad 480 \quad 490 \quad 500 \quad 510 \quad 520$

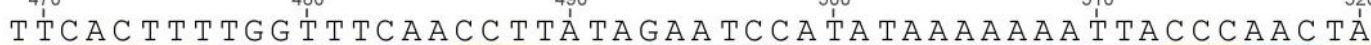

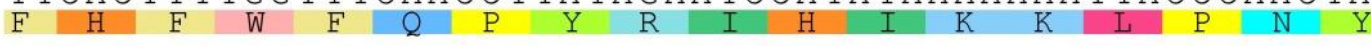

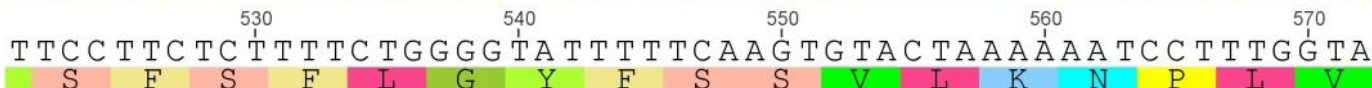

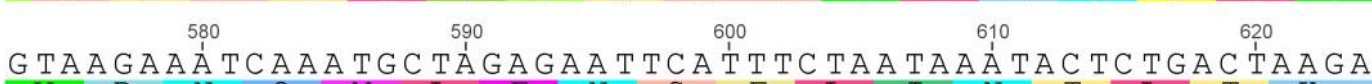

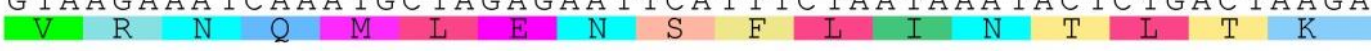
$630 \quad 640 \quad 650 \quad 660 \quad 670$

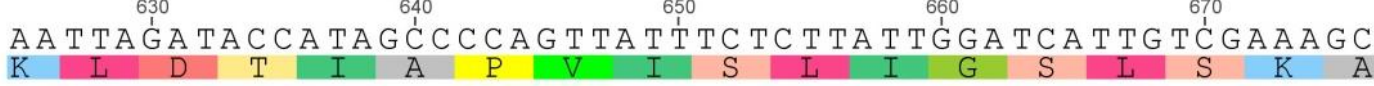
$680 \quad 690 \quad 700 \quad 710 \quad 720$

TCA ̈ T T T TG TACTG TATTGGGTCÀTCCTATTAG TAAACCGATC T⿱宀 TGACCGAT

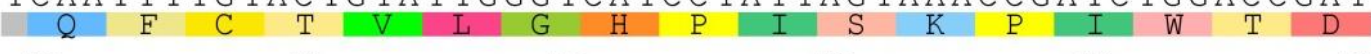

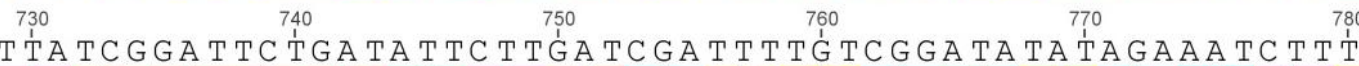

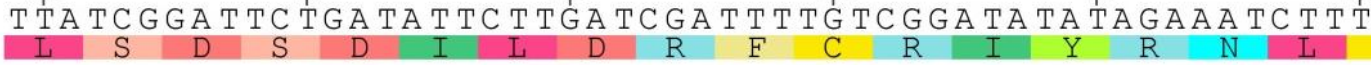

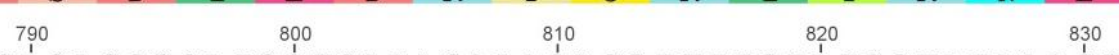
G TCGTTATC $\dot{A}$ CAGCGGATC

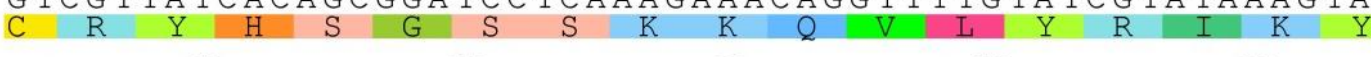

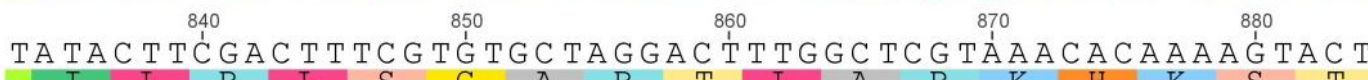

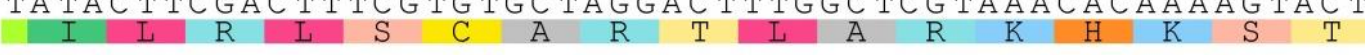
G T A C $\stackrel{889}{1}$

Gambar 2. Sekuens DNA barcode matK dan Asam Amino 


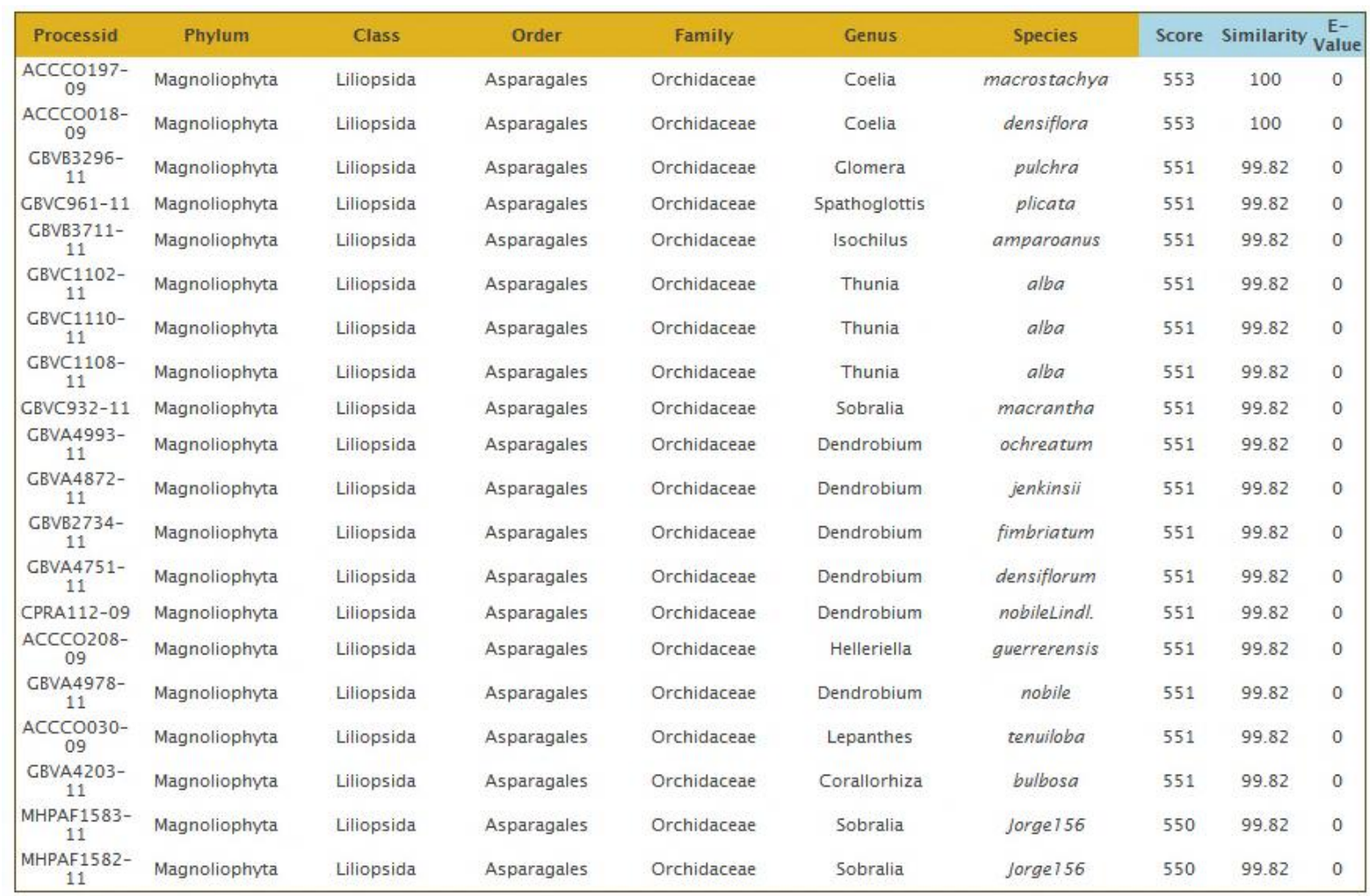

Gambar 3. Penelusuran BOLD Systems untuk Sekuens rbcL Tanaman Payus Limondok (Phaius tancarvilleae) Tanggal 8 Agustus 2012

\begin{tabular}{|c|c|c|c|c|c|c|c|c|c|}
\hline Processid & Phylum & Class & Order & Family & Genus & Species & Score & Similarity & $\begin{array}{l}\text { E- } \\
\text { Value }\end{array}$ \\
\hline GBVC076-11 & Magnoliophyta & Liliopsida & Asparagales & Orchidaceae & Phaius & tancarvilleae & 837 & 100 & 0 \\
\hline $\begin{array}{c}\text { GBVB2455- } \\
11\end{array}$ & Magnoliophyta & Liliopsida & Asparagales & Orchidaceae & Coelia & triptera & 797 & 97.61 & 0 \\
\hline $\begin{array}{c}\text { GBVB2963- } \\
11\end{array}$ & Magnoliophyta & Liliopsida & Asparagales & Orchidaceae & & & 797 & 97.61 & 0 \\
\hline $\begin{array}{c}\text { GBVB2405- } \\
11\end{array}$ & Magnoliophyta & Liliopsida & Asparagales & Orchidaceae & Calanthe & vestita & 796 & 97.84 & 0 \\
\hline $\begin{array}{c}\text { GBVB2381- } \\
11\end{array}$ & Magnoliophyta & Liliopsida & Asparagales & Orchidaceae & Bothriochilus & bellus & 795 & 97.49 & 0 \\
\hline $\begin{array}{c}\text { GBVB3092- } \\
11\end{array}$ & Magnoliophyta & Liliopsida & Asparagales & Orchidaceae & Encyclia & dichroma & 793 & 97.37 & 0 \\
\hline $\begin{array}{c}\text { GBVB2469- } \\
11\end{array}$ & Magnoliophyta & Liliopsida & Asparagales & Orchidaceae & Coelogyne & cristata & 793 & 97.37 & 0 \\
\hline $\begin{array}{c}\text { GBVA4 } 130- \\
11\end{array}$ & Magnoliophyta & Liliopsida & Asparagales & Orchidaceae & Coelogyne & cristata & 793 & 97.37 & 0 \\
\hline $\begin{array}{c}\text { GBVB3100- } \\
11\end{array}$ & Magnoliophyta & Liliopsida & Asparagales & Orchidaceae & Encyclia & randii & 791 & 97.25 & 0 \\
\hline GBVC114-11 & Magnoliophyta & Liliopsida & Asparagales & Orchidaceae & Pholidota & chinensis & 791 & 97.25 & 0 \\
\hline $\begin{array}{c}\text { GBVA4154- } \\
11\end{array}$ & Magnoliophyta & Liliopsida & Asparagales & Orchidaceae & Collabium & sp.Chaseo-821 & 790 & 97.37 & 0 \\
\hline $\begin{array}{c}\text { GBVB2376- } \\
11\end{array}$ & Magnoliophyta & Liliopsida & Asparagales & Orchidaceae & Bletia & rosea & 789 & 97.13 & 0 \\
\hline $\begin{array}{c}\text { GBVA3860- } \\
11\end{array}$ & Magnoliophyta & Liliopsida & Asparagales & Orchidaceae & Bletia & purpurea & 789 & 97.13 & 0 \\
\hline $\begin{array}{c}\text { GBVB2744- } \\
11\end{array}$ & Magnoliophyta & Liliopsida & Asparagales & Orchidaceae & Dendrobium & kingianum & 788 & 97.13 & 0 \\
\hline $\begin{array}{c}\text { GBVB4452- } \\
11\end{array}$ & Magnoliophyta & Liliopsida & Asparagales & Orchidaceae & Microepidendrum & subulatifolium & 787 & 97.01 & 0 \\
\hline CBVC638-11 & Magnoliophyta & Liliopsida & Asparagales & Orchidaceae & Rhyncholaelia & glauca & 787 & 97.01 & 0 \\
\hline GBVC400-11 & Magnoliophyta & Liliopsida & Asparagales & Orchidaceae & Ponera & striata & 787 & 97.01 & 0 \\
\hline GBVC077-11 & Magnoliophyta & Liliopsida & Asparagales & Orchidaceae & Phaius & tancarvilleae & 786 & 100 & 0 \\
\hline $\begin{array}{c}\text { GBVB3063- } \\
11\end{array}$ & Magnoliophyta & Liliopsida & Asparagales & Orchidaceae & Elleanthus & cynarocephalus & 785 & 96.89 & 0 \\
\hline GBVC832-11 & Magnoliophyta & Liliopsida & Asparagales & Orchidaceae & Scaphyglottis & amparoana & 785 & 96.89 & 0 \\
\hline
\end{tabular}

Gambar 4. Penelusuran BOLD Systems untuk Sekuens matK Tanaman Payus Limondok (Phaius tancarvilleae) Tanggal 8 Agustus 2012 
Kemampuan diskriminasi (discrimination power) barcode rbcL telah diperkirakan oleh beberapa publikasi ilmiah yang merekomendasikan barcode menggunakan gen ini (Hollingsworth et al. 2009, 2011). Meskipun tidak memiliki kemampuan diskriminasi terbaik tetapi barcode rbcL memiliki tingkat keberhasilan amplifikasi yang tinggi untuk banyak spesies serta mudah untuk disekuensing (Hollingsworth et al., 2011). Meskipun demikian, kemampuan barcode rbcL dalam penelitian ini hanya mampu membedakan sampel yang ada sampai pada tingkat famili saja.

Di dalam hal variasi interspesies, barcode matK memiliki kemampuan pembeda yang lebih baik untuk identifikasi sampel dalam penelitian ini. Kecepatan mutasi pada gen matK memegang peranan penting dalam variasi intraspesifik. Meskipun perbedaan secara genetik sesama anggota famili Orchidaceae yang berkerabat dekat dengan $P$. tancarvilleae hanya kurang dari $2 \%$, perbedaan ini cukup untuk identifikasi sampai pada tingkat spesies. Miripnya sekuens spesies $P$. tancarvilleae menunjukkan juga variasi intraspesifik yang sedikit. Rekomendasi yang bisa diberikan untuk identifikasi atau konfirmasi spesies ini adalah dengan melihat sekuens barcode matK.

\section{KESIMPULAN}

\begin{tabular}{lcr}
\multicolumn{2}{c}{ Berdasarkan $\begin{array}{c}\text { hasil } \\
\text { pembahasan }\end{array}$ maka } & dapat \\
disimpulkan & bahwa & dengan \\
terdapatnya & kemiripan & $100 \%$
\end{tabular} sekuens anggrek $P$. tancarvilleae dengan dua spesies kerabat dekatnya maka barcode DNA rbcL tidak dapat digunakan untuk identifikasi tingkat spesies. Kemampuan diskriminasi barcode matK untuk tanaman $P$. tancarvilleae lebih baik daripada barcode $r b c L$ sehingga dapat digunakan untuk identifikasi spesies secara akurat. Tidak terdapat variasi intraspesifik berdasarkan sekuens barcode matK antara $P$. tancarvilleae sampel penelitian dengan yang sampel yang sudah terdata di dalam BOLD Systems.

\section{DAFTAR PUSTAKA}

Dick CW, Kress WJ (2009) Dissecting tropical plant diversity with forest plots and a molecular toolkit. Bioscience 59: 745-755

Drummond AJ, Ashton B, Buxton S, Cheung $M$, Cooper A, Duran C, Field M, Heled J, Kearse M, Markowitz S, Moir R, Stones-Havas S, Sturrock S, Thierer T, Wilson A (2012) Geneious v5.6. Biomatters. New Zealand

Edgar RC (2004) MUSCLE: Multiple sequence alignment with high accuracy and high throughput. Nucleic Acid Res. 32 (5): 1792-1797

Hebert, P.D.N., Cywinska, N.A., Ball, S.L. dan de Waard, J.R. (2003) Biological identifications through DNA barcodes. Proc. Roy. Soc. BBiol. Sci. 270: 313-321

Hollingsworth PM, Graham SW, Little DP (2011) Choosing and using a plant DNA barcode. PloSONE (6): e19254

Hollingsworth PM, Forrest LL, Spouge JL, Hajibabaei M, Ratnasingham R (2009) A DNA barcode for land plants. Proc. Natl. Acad. Sci. USA. 106: 12794-12797

Kress WJ, Erickson DL (2007) A two-locus global DNA barcode for land plants: the coding $r b c L$ gene complements the non-coding trnH-psbA spacer region. PLOSONE 2 (6): e508

Lahaye $R$, Van der Bank M, Bogarin D, Warner J, Pupulin F, Gigot 
G, Maurin O, Duthoit S, Barraclough TG, Savolainen V (2008) DNA barcoding the floras of biodiversity hotspots. Proc. Nat. Acad. Sci., 105(8): 2923-2928

Pfahl J (2012a) Coelia macrostachys.

http://www.orchidspecies.co m/coeliac macrostachys.htm [diakses pada 10 Agustus 2012]

Pfahl J (2012b) Coelia densiflora. http://www.orchidspecies.co m/coeldensi flora.htm [diakses pada 10 Agustus 2012]

Ratnasingham S, Hebert PDN (2007) BOLD: The barcode of life data system. Molecular Ecology Notes 7: 355-364

Stoeckle MY, Gamble CC, Kirpekar R, Young G, Ahmed S, Little DP (2011) Commercial teas highlight plant DNA barcode identification successes and obstacles. Sci. Rep. 1(42): 17

Xue CY, Li DZ (2011) Use of dna barcode sensu lato to identify traditional Tibetan medicinal plant Gentianopsis paludosa (Gentianaceae). J. Sys. Evol., 49 (3): 267-270 